\title{
Determinants of Adoption of Soil and Water Conservation Technologies in Coffee-Growing Areas of Ethiopia
}

\author{
Kalkidan Fikirie \\ EIAR, Holeta Agricultural Research Center, P. O. Box 31, Holeta, Ethiopia.
}

\begin{abstract}
How to cite this paper: Kalkidan Fikirie. (2021) Determinants of Adoption of Soil and Water Conservation Technologies in Coffee-Growing Areas of Ethiopia. International Journal of the Science of Food and Agriculture, 5(1), 189-198. DOI: 10.26855/ijfsa.2021.03.025
\end{abstract}

Received: February 7, 2021

Accepted: March 4, 2021

Published: March 29, 2021

*Corresponding author: Kalkidan Fikirie, EIAR, Holeta Agricultural Research Center, P. O. Box 31, Holeta, Ethiopia.

Email: kalkidanfikire@gmail.com

\begin{abstract}
Soil erosion is a threat to the economic development of Ethiopia as it affects the agricultural sector significantly. Even if several SWC practices were introduced and implemented to combat soil erosion, the adoption of these practices remains below the expectations. This study aimed to investigate the main factors that influence the adoption of physical SWC practices in coffee-growing areas of Ethiopia. The study used quantitative and qualitative primary data collected from subsistence farmers and other stakeholders from major coffee-growing areas of the country (Oromia and SNNP). Binary Logistic Regression (BLR) model was used to examine factors that affected the adoption of physical SWC practices. The study result showed that $49 \%$ and $44 \%$ of farmers used physical SWC practices on their land along Oromia and SNNP, respectively. Soil bund is a commonly used conservation practice in the study regions. Out of the adopters of physical SWC measures, 45\% constructed soil bund which is higher at Oromia (53\%) and low in the SNNP region (37\%). The finding of the study also indicated the positive and significant effect of education, extension (access to extension services and participation on field days), and ownership of communication devices especially radio on the adoption of physical SWC practices. The study suggests policymakers and public authorities give due attention to problems affecting effective farmers-extension linkage. The farmers' training center system which is partially functioning currently should be strengthened to its full capacity. The positive effect of radio ownership on technology adoption also suggests the need for launching FMs channels to farmers which initially focuses on the provision of SWC practices information and knowledge.
\end{abstract}

\section{Keywords}

Extension, Land degradation, Logistic, Soil erosion, and SWC practices

\section{Introduction}

Ethiopian economy is heavily dependent on rain-fed agriculture which is dominated by smallholder farmers that are partially integrated into markets [1]. The outcome of the agricultural sector directly affects economic development, food security, and also poverty alleviation of the country [2,3]. However, the role of this sector is hurt by land degradation such as soil erosion and nutrient depletion $[4,5,6]$.

Studies showed that in Ethiopia, the soil loss rate ranges from 16 to $300 \mathrm{Mgha}^{-1} \mathrm{yr}^{-1}$. The loss is highly dependent on the degree of slope gradient, land cover, soil type, and the nature of rainfall intensities [7]. Despite this, annual soil loss is diverse in space and time. For instance, [8] estimated annual soil loss of $93 \mathrm{Mgha}^{-1} \mathrm{yr}^{-1}$ for the entire Chemago watershed. Haile and Fetene [6] also estimated that about $97 \%$ of Kilie catchment has $0-10 \mathrm{Mgha}^{-1} \mathrm{yr}^{-1}$ erosion rate. In the same manner [9] pointed out that in Borena district of south Wello, the rate of soil loss was estimated to be 10 to 80 
Mgha $^{-1} \mathrm{yr}^{-1}$. About, 75\% of the total area of the Gerado catchment, Northeastern Ethiopia, was found to have rates of soil losses which were $>25 \mathrm{Mgha}^{-1} \mathrm{yr}^{-1}$. Alongside, [10] estimated the highest soil loss at Medego watershed (35.4 $\mathrm{Mgh}^{-1} \mathrm{yr}^{-1}$ ) on the slope of $30 \%-50 \%$.

Generally, from 1981 to 2008, the total land degraded in the country was estimated to be 297,000 $\mathrm{Km}^{2}$ [11]. The mean rates of soil loss associated with croplands have been about $42 \mathrm{Mgha}^{-1} \mathrm{yr}^{-1}$ across the country $[12,13,14]$ and recent estimates by [15] indicated rates of $20 \mathrm{Mgha}^{-1} \mathrm{yr}^{-1}$ on currently cultivated lands and $33 \mathrm{Mgha}^{-1} \mathrm{yr}^{-1}$ on formerly cultivated degraded lands.

Population pressure, inappropriate farming practices, and poor watershed management have contributed to a lion's share of the losses caused. Moreover, soil erosion hampers agricultural productivity through declining soil quality through excessive surface runoff, and also soil erosion causes the change in the physical properties of the soil [16].

Recognizing soil erosion as a major environmental and socio-economic problem, the Ethiopian government has designed and implemented a comprehensive sustainable land management project that focuses on a compromise between top-down and bottom-up approaches to watershed management activities [17, 18, 19, 20, 13, 14, 21, 11].

This watershed management approach has been implemented to minimize environmental degradation and enhance agricultural productivity which supports sustainable livelihoods security of the households.

The use of soil and water conservation (SWC) practices in association with crop production is determined by the combined effect of biophysical and socio-economic factors [22]. Consequently, the adoption of soil and water conservation practices in developing countries such as Ethiopia is very low and the expected change is far below the efforts done $[23,24]$.

Many introduced technologies have been rejected by farmers since they are simply inappropriate for the specific condition of small farm systems. Likewise, in Ethiopia, various factors were barriers to the full-scale implementation of SWC technologies. These include lack of awareness of soil erosion, institutional, socio-cultural, structural, environmental, and economic issues, lack of provision of adequate information on the technical details of innovation, inadequate extension services, and poor linkages with research teams, education, and poor transportation and communication networks, family size, land size, livestock holding, access to credit and training [25, 26, 27].

Therefore, this study focused on the main institutional, socio-economic, and bio-physical drivers for the adoption of SWC technologies in the coffee-based farming system of Ethiopia where conservation innovations are ignored and undermined. The farming system is characterized by undulating topography. However, poor adoption of soil and water conservation practices is the main feature of the area which has derived the farming system to high termite problems and acidic soil. The purpose of the study was to study the adoption of different soil and water conservation methods. Moreover, the study was anticipated to investigate determinant factors that affect physical soil and water conservation structures in the coffee-growing areas of Ethiopia.

\section{Methodology}

\subsection{Study area description and the data}

The study used quantitative and qualitative primary data collected from subsistence farmers and other stakeholders (experts, district, and zone officials) from coffee-growing regions of the country: Oromia and SNNP regions. Ilubabor, Jimma, West, and Kellem Wollega zones from Oromia, and Gedeo, Sidama, Kaffa, and Sheka zones were selected from SNNP regions.
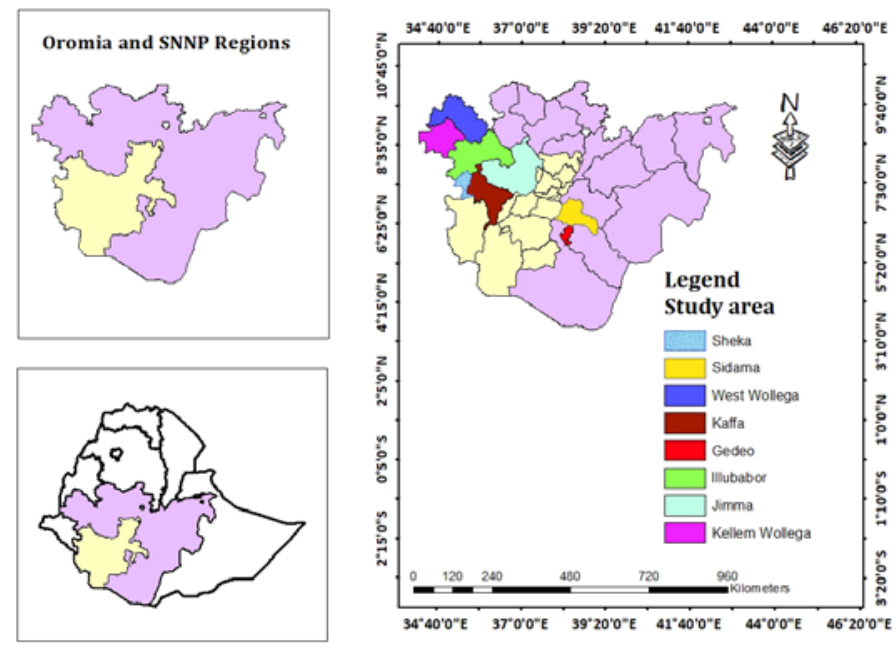

Figure 1. Map of the study area. 


\subsection{Sampling and data collection}

A multistage sampling technique was employed to select the population for the study which involved both purposive and random sampling techniques. First, regions and zones were purposively selected based on the number of coffee growers, the area allocated for coffee, and the quantity of coffee produced. Accordingly, Oromia and SNNP regions were purposively chosen for the study since these regions alone accounted for $89 \%$ of coffee growers, $97 \%$ of the coffee area, and $99 \%$ of the coffee production of the country [28]. Secondly, districts and peasant associations were selected using a random sampling technique. Lastly, households were randomly chosen from the sampling frame of the coffee grower population at the peasant association level. Ultimately, a total of 953 sample households were selected for the study (584 from SNNP and 369 from Oromia Regions) (Table 1). Data were collected from the sampled households through a structured questionnaire administered to sampled farmers.

Table 1. Total sample size and sample distribution along study zones

\begin{tabular}{|c|c|c|c|}
\hline Region & Zones & Total sample size & $\%$ of the total \\
\hline & Gedeo & 199 & 21 \\
\hline & Sidama & 200 & 21 \\
\hline \multirow[t]{4}{*}{ SNNP } & Sheka & 81 & 8 \\
\hline & Kaffa & 104 & 11 \\
\hline & Sub-total & 584 & 61 \\
\hline & Ilubabor & 121 & 13 \\
\hline \multirow[t]{5}{*}{ Oromia } & Jimma & 107 & 11 \\
\hline & West Wollega & 105 & 11 \\
\hline & Kellem Wollega & 36 & 4 \\
\hline & Sub-total & 369 & 39 \\
\hline & & 953 & 100 \\
\hline
\end{tabular}

Source: computed from the data, 2019.

\subsection{Data Analysis}

Data were analyzed using descriptive statistics and econometric models. A logistic model was used to identify factors affecting the adoption of physical soil and water conservation structures. Hill and Kau [29] and Pindyck and Rubinfeld [30] reported for a farmer to adopt or not to adopt a specific technology, a reaction threshold of different factors affect. As such, at a certain value of stimulus below the threshold, no adoption is observed while at the critical threshold value, a reaction is stimulated. This is modeled as:

$$
Y_{I}=\beta X_{i}^{*}+\mu_{i}
$$

Where $\mathrm{Yi}$ is equal to one (1) when a choice is made to adopt and zero (0) otherwise and $\mathrm{X}^{*}$ represents the combined effects of the independent variables $(\mathrm{Xi})$ at the threshold level. The above binary choice model involves the estimation of the probability of adoption of a given technology (Y) as a function of independent variables (X). The probability of adoption and non-adoption is also modeled as:

$$
\begin{aligned}
& \operatorname{prob}\left(Y_{i}=1\right)=F\left(\beta^{\prime} X_{i}\right) \ldots \ldots \\
& \operatorname{prob}\left(Y_{i}=0\right)=1-F\left(\beta^{\prime} X_{i}\right) .
\end{aligned}
$$

Where $\mathrm{Yi}$ is the observed response for the $\mathrm{i}^{\text {th }}$ observation of the response variable $\mathrm{Y}$ and $\mathrm{Xi}$ is a set of independent variables such as farm size among others, associated with the $i^{\text {th }}$ individual, which determines the probability of adoption, (P). The function, F may take the form of a normal, logistic, or probability function. The empirical model for the logit model estimation is specified as:

$$
z_{i}=\log \left(\frac{p_{i}}{1-p_{i}}\right)=\alpha+\beta^{\prime} X_{i}+\varepsilon_{i}
$$

Where $\mathrm{Xi}$ is the combined effect of $\mathrm{X}$ explanatory variables that promote or prevent farmers' decision to adopt modern agricultural production technologies and is the log-odds in favor of farm households' decision to adopt modern 
agricultural technologies.

\section{Result and Discussions}

\subsection{Characteristics of survey respondents}

The study was considered different explanatory variables that could affect the adoption of physical soil and water conservation practices. According to the survey result, $90 \%$ of farmers were male-headed households. Age and family size were affecting the adoption of physical soil and water conservation practices. The mean age of the household head was 42 years old and the statistical result shows that there was no significant difference between the two regions in the age of household. The mean family size of the respondents along the region was 6 members and the mean number of years of education of the whole family and household head was 3.97 and 3.82 years, respectively. The mean distance from homestead to farm plots was $2.6 \mathrm{kms}$ with a maximum of $11 \mathrm{kms}$, and $37 \%$ of farmers have access to credit services. The mean total land in the study area was 1.8 hectares, besides farmers also have on average 4.2 tropical livestock units (TLU). Coffee is the main cash crop in the study area. The study also included coffee adoption as an explanatory variable since the adoption of coffee could affect the adoption of soil and water conservation practices. The study result showed $60 \%$ of farmers have adopted improved coffee. Only $25 \%$ of farmers also participate in off-farm income-generating activities (Table 2).

Table 2. Description and summary statistics of explanatory variables

\begin{tabular}{|c|c|c|c|c|c|}
\hline Variables & No. of Observation & Mean & SD & Min & $\operatorname{Max}$ \\
\hline Region & 953 & 0.612 & 0.487 & 0 & 1 \\
\hline Sex & 953 & 0.902 & 0.297 & 0 & 1 \\
\hline Age & 953 & 42.62 & 12.28 & 21 & 90 \\
\hline Family size & 951 & 6.328 & 2.343 & 1 & 17 \\
\hline Household head education level (years) & 953 & 4.811 & 3.489 & 0 & 16 \\
\hline Distance from homestead to farm plots in $\mathrm{km}$ & 919 & 2.631 & 2.557 & 0 & 11 \\
\hline Radio ownership & 953 & 0.54 & 0.498 & 0 & 1 \\
\hline Credit access & 953 & 0.372 & 0.481 & 0 & 1 \\
\hline Extension service on soil and water management & 953 & 0.852 & 0.355 & 0 & 1 \\
\hline Participation on field days & 953 & 0.243 & 0.429 & 0 & 1 \\
\hline Participate in off-farm income-generating activities & 953 & 0.251 & 0.424 & 0 & 1 \\
\hline Total land in hectares & 928 & 1.756 & 1.788 & 0.01 & 12 \\
\hline Tropical Livestock Unit (TLU) in numbers & 953 & 4.154 & 4.426 & 0 & 19 \\
\hline Improved coffee variety adoption & 953 & 0.601 & 0.495 & 0 & 1 \\
\hline
\end{tabular}

Source: computed from the data, 2019.

\subsection{Respondents' access to extension services}

In Ethiopia, the population is growing at an alarming rate and the demand for food is increasing. Feeding the growing population depends on securing and advancing the use of improved technology and approaches especially in Africa. Numerous farmers in such countries, though, continue to cultivate crops and raise livestock in the same ways that have been used in their communities for generations due to poor farmers-extension linkage and lack of access to inputs and markets. This survey showed that $86 \%, 78 \%$, and $85 \%$ of respondents were provided extension services on crop production, livestock production, and natural resource management which is better despite the quality of the services. Alongside, farmers in the Oromia region have relatively better access to extension than the SNNP region counterparts (Figure 2).

Figure 3 depicted that, more than 20\% of farmers have participated in demonstration or field days in both regions. There was an insignificant difference between the two regions in both training and field day participation. 


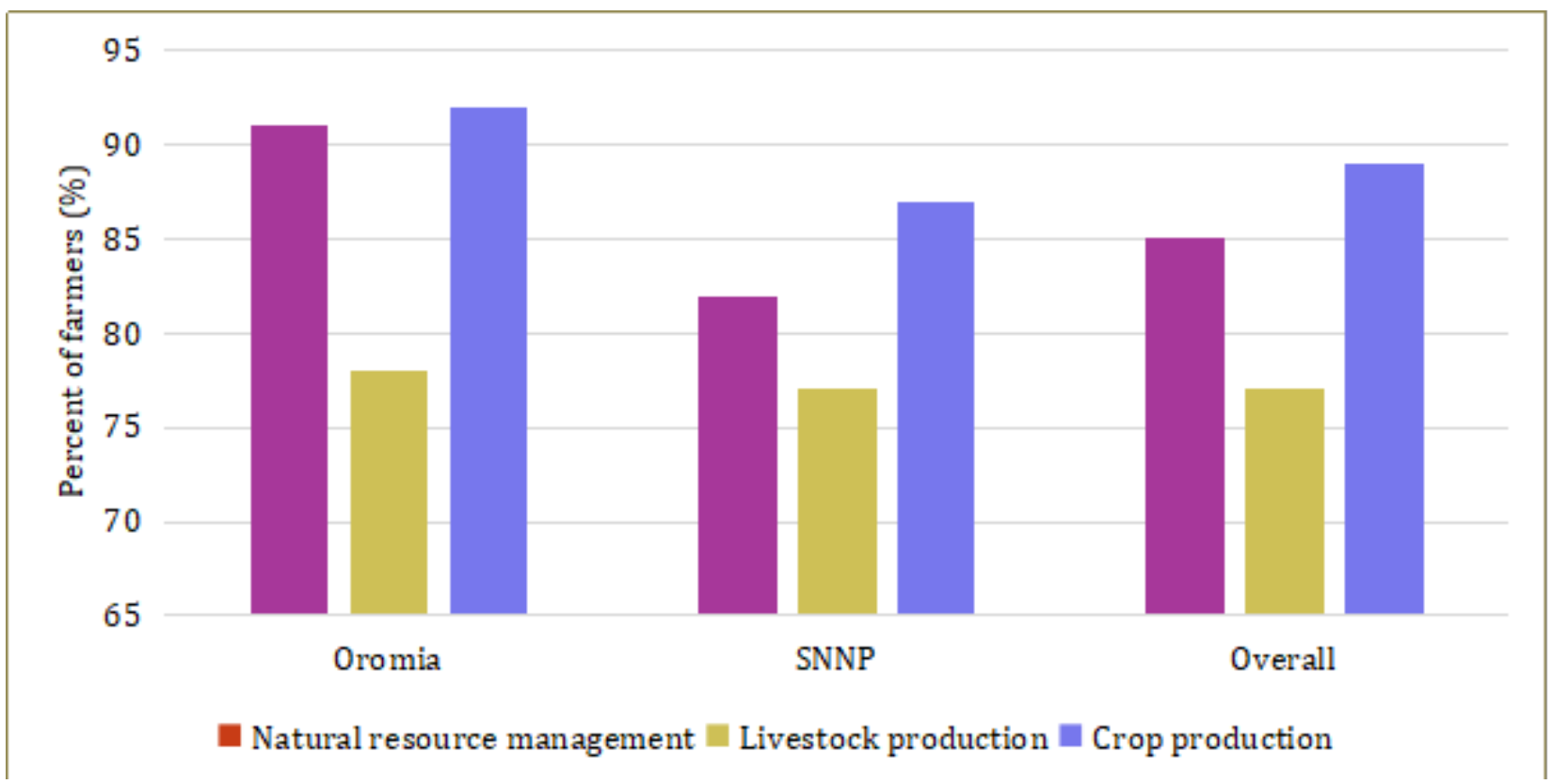

Figure 2. Farmers' access to extension services along the study regions in \% (Source: computed from the data, 2019).

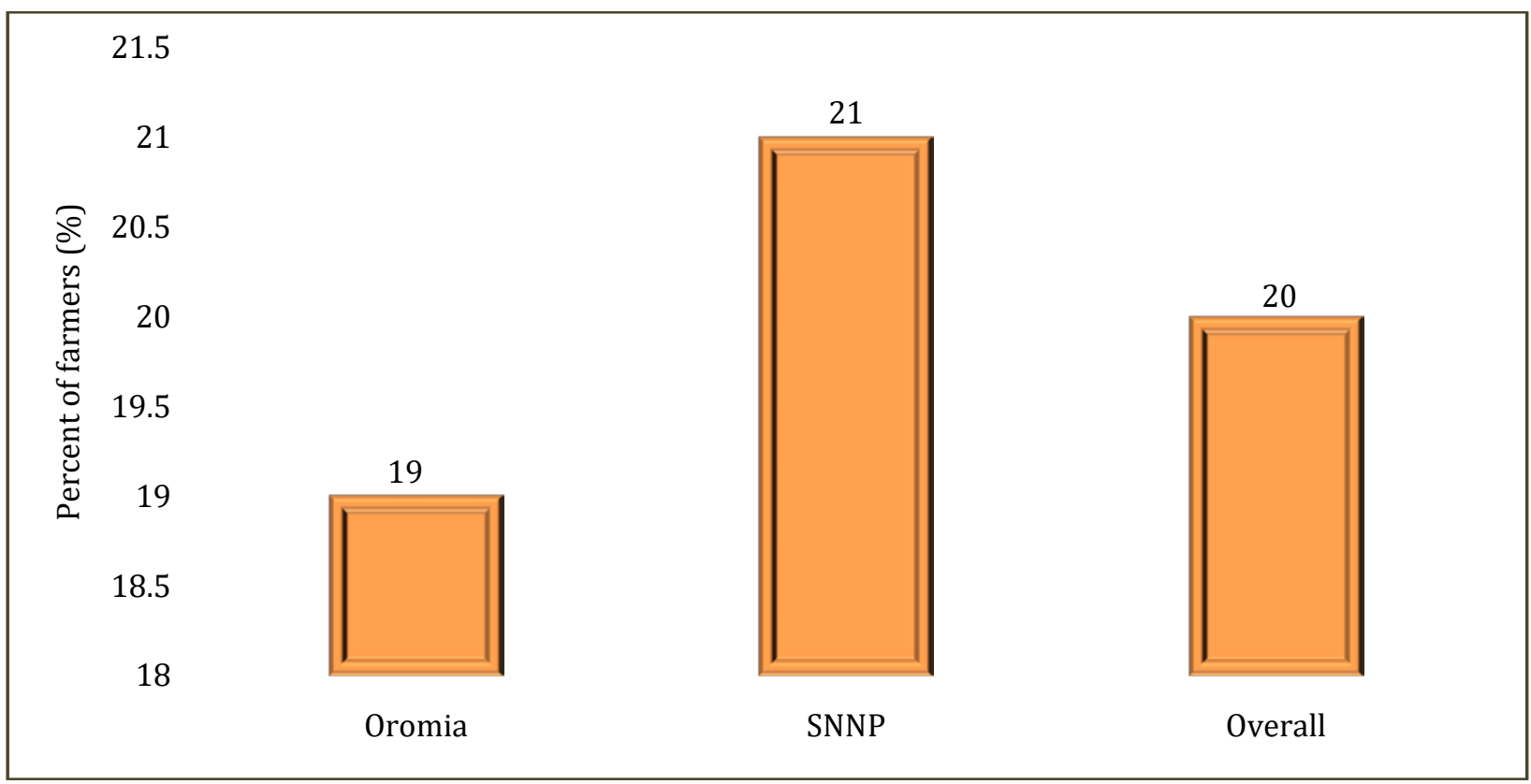

Figure 3. Farmers' participation in training and field days along study regions in \% (Source: computed from the data, 2019).

\subsection{Respondents' use of communication technologies}

Communication in agriculture is crucial for producers to adopt the new agricultural technologies, sell the output, purchase the inputs, and mitigate the agricultural risks and disasters. It is the device used to transfer and/or receive information and knowledge.

The survey result assessed farmers' communication asset ownership along the study regions. The result exhibited that the majority of farmers owned mobile phones (63\%) and functional radio (54\%) in both Oromia and SNNP regions. Only a few farmers with access to electric power owned TV (11\%). There was a significant difference between the Oromia and SNNP regions in the ownership of these communication technologies. A high number of farmers in SNNP owned both mobile phones and TV than farmers in the Oromia region (Table 3). 
Table 3. Farmers asset ownership along the regions in \%

\begin{tabular}{ccccc}
\hline Assets & Oromia & SNNP & Pooled & P-value \\
\hline Mobile Phone & 58 & 69 & 63 & $0.000^{* * *}$ \\
Functional Radio & 63 & 45 & 54 & $0.000^{* * *}$ \\
Functional TV & 8 & 13 & 11 & $0.035^{* *}$ \\
\hline
\end{tabular}

Notes. $^{* * *} \mathrm{p}<0.01,{ }^{* *} \mathrm{p}<0.05,{ }^{*} \mathrm{p}<0.1$. Source: computed from the data, 2019.

\subsection{Farmers adoption of minimum tillage}

Minimum tillage involves minimizing the number of tillage operations by making only limited slots for placing the seed, either by using specialized machines (seeders) that open up small furrows in which the seed is placed or by manually using hoes or dipsticks to bore holes into which seeds are placed. Its purpose is to minimize soil disturbance since the rest of the field is left untilled [31, 32].

Farmers use minimum tillage to mitigate the effect of termites and soil acidity in the study areas. The use of minimum tillage was higher at SNNP than in the Oromia region with an overall mean of 36\% (Figure 4). There was a significant difference between regions in the adoption of minimum tillage. Farmers in SNNP operate on small land size and plowing the land yearly could decline the soil fertility. Thus, they prefer minimum tillage to mitigate erosion which is the primary cause of soil fertility loss.

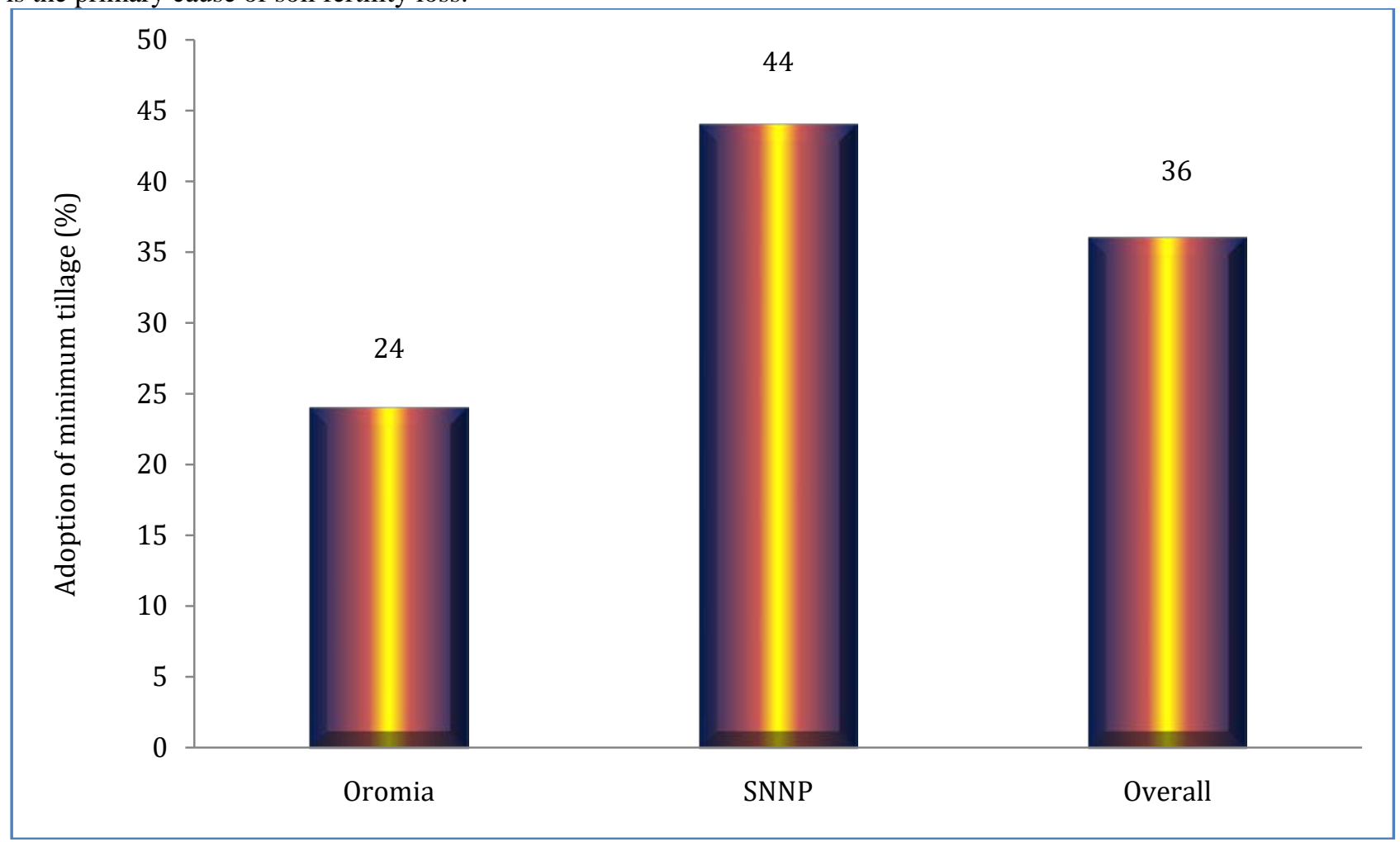

Figure 4. Adoption of minimum tillage in \% (Source: computed from the data, 2019).

\subsection{Farmers adoption of soil and water conservation structures}

Land degradation in the form of soil erosion is the main challenge for sustainable development in the country. The degradation of land and soil erosion has adverse impacts on food security, soil nutrient depletion, water pollution, human health, and social and economic activities [33].

Due to the undulating topography of the coffee farming system and high intensity of soil acidity and termites as well as due to large space between coffee plants, farmers use different techniques of soil and water conservation practices to mitigate the problems and increase productivity per unit of land. These include fallowing, area closure, use of inorganic fertilizers, manure application, application of decomposed coffee husk, conservation tillage, intercropping, and cover cropping in coffee, the use of improved fodder, crop rotation, soil, and water management practices, and others. In this study, we have considered physical soil and water conservation practices. Addressing land degradation and soil erosion 
through sustainable management of soil and land over physical soil and water conservation methods offers tremendous potential for climate change adaptation and mitigation as well as to enhance and sustain land productivity as well as to increase water productivity. Accordingly, this study has assessed the use of different physical soil and water conservation practices. The result showed that $49 \%$ of farmers in the Oromia region use the SWC structures which are higher as compared to the SNNP region (44\%). Oromia region is characterized by undulling topography and high soil acidity and Termite is also the main production constraint in the region. SWC Conservation structures are recommended to combat the termites and reduce the soil acidity. This has derived the Oromia farmers to adopt SWC structures than farmers in the SNNP region. On average, $47 \%$ of respondents used soil and water conservation structures on their land along the study regions (Figure 5).

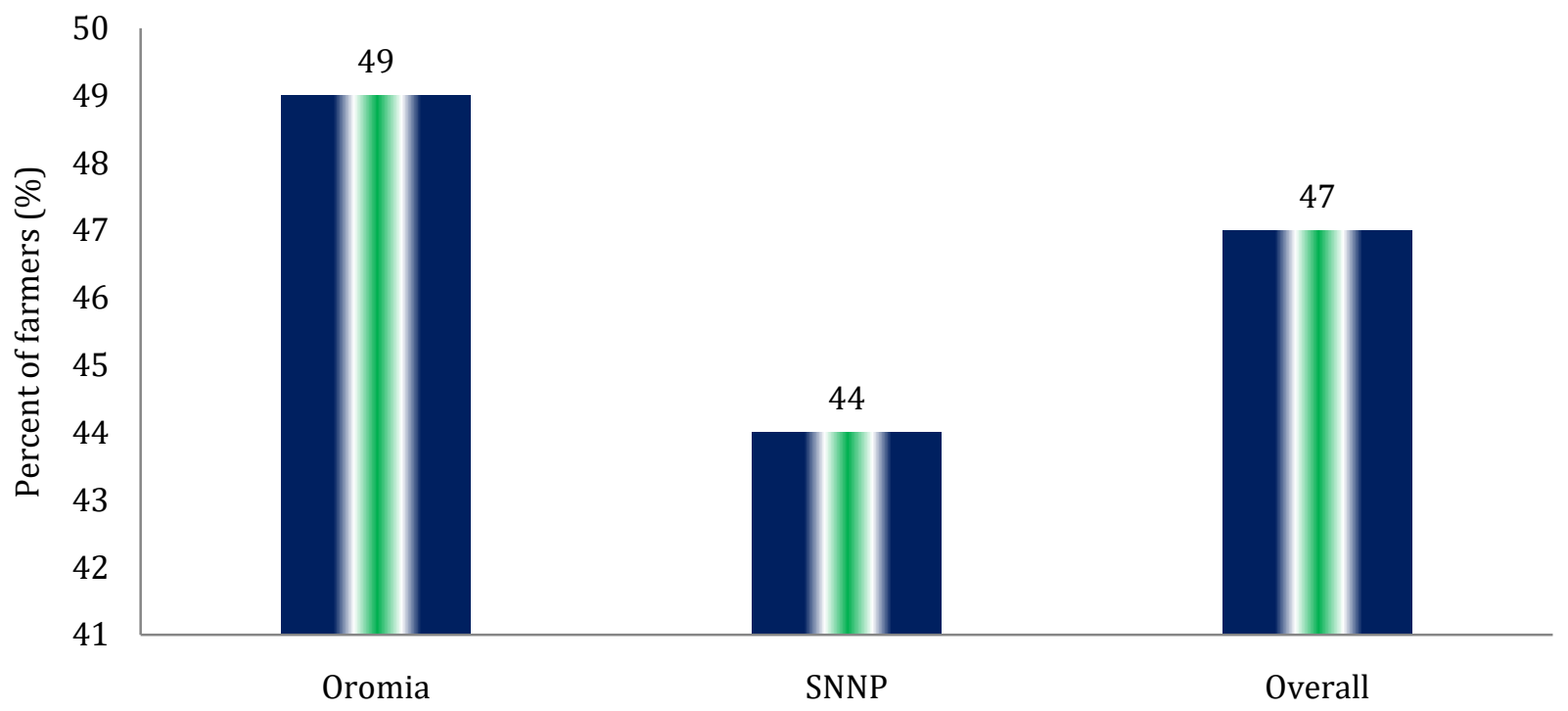

Figure 5. Adoption of physical soil and water conservation structures in \% (Source: computed from the data, 2019).

Soil bund is a commonly used conservation practice in the study regions. Out of the adopters of physical soil and water conservation measures, $45 \%$ constructed soil bund which is higher at Oromia (53\%) and low in the SNNP region (37\%). The use of terracing and stone bunds also follows soil bund use among farmers of the study area (Figure 6).

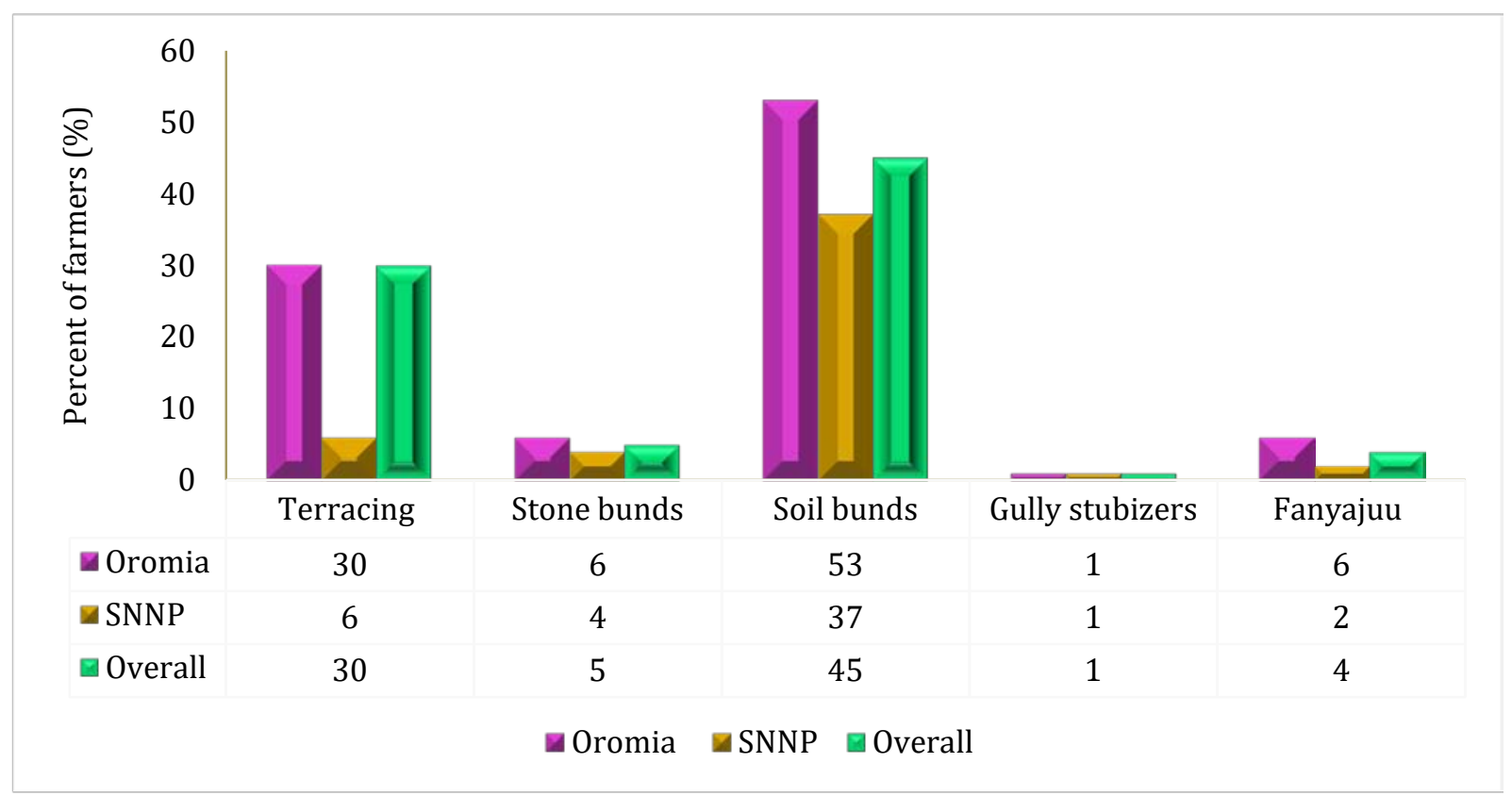

Figure 6. Type of physical soil and water conservation structures used in \% (Source: computed from the data, 2019). 


\subsection{Factors affecting the adoption of physical soil and water conservation structures}

The result of the logit model showed that the South nation nationality and people (SNNP) region is negatively related to the adoption of physical soil and water conservation structures which imply that the SNNP region is less adopter of the structures than the Oromia region. Oromia region farmers adopted the SWC structures highly and significantly to combat the problem of termite and soil acidity which is substantially high in the area due to high soil erosion. The result also supports the finding of descriptive statistics.

Source of information and knowledge such as ownership of radio, training, and access to extension services affect the adoption of physical soil and water conservation structures positively and significantly. The positive relationship between the adoption of physical soil and water conservation structures and extension service was also found by [34, 35, 36, 37, 38].

Better exposure to education increases farmers' better understanding of the benefits and constraints. Nonetheless, the result contrasts with [39].

Both oxen ownership and TLU positively and significantly affect the adoption of physical soil and water conservation measures. Since the investment in SWC structures is expensive (labor, time, and capital intensive), those farmers who have more TLU have the advantage to sell the livestock and use the money of the investment on conservation. The result is consistent with [25, 40, 41, 42, 43, 27] and contrasts with [7] and [44].

Table 4. Factors affecting adoption physical SWC practices

\begin{tabular}{|c|c|c|c|c|}
\hline Variables & Coefficient & $S E$ & t-value & P-value \\
\hline Region (SNNP) & -0.66 & 0.183 & -3.61 & $0.000^{* * *}$ \\
\hline Household head sex (Male) & 0.209 & 0.258 & 0.81 & 0.418 \\
\hline Household head age & 0.002 & 0.006 & 0.33 & 0.742 \\
\hline Household head education in number of years & 0.032 & 0.034 & 0.94 & 0.348 \\
\hline Distance from homestead to farm plots & -0.004 & 0.013 & -0.31 & 0.757 \\
\hline Participation of field days (Yes) & 0.51 & 0.199 & 2.57 & $0.010^{* *}$ \\
\hline Extension services (Yes) & 1.55 & 0.238 & 6.52 & $0.000^{* * *}$ \\
\hline Radio ownership (Yes) & 0.273 & 0.161 & 1.69 & $0.090^{*}$ \\
\hline Total land in hectares & -0.068 & 0.055 & -1.23 & 0.22 \\
\hline$T L U$ & 0.085 & 0.024 & 3.46 & $0.001^{* * *}$ \\
\hline Oxen ownership (yes) & 0.371 & 0.223 & 1.67 & $0.096^{*}$ \\
\hline Training on natural resource management (Yes) & 0.443 & 0.17 & 2.6 & $0.009^{* * *}$ \\
\hline Credit services (Yes) & -0.007 & 0.159 & -0.04 & 0.967 \\
\hline Participation on off-farm income generating activities (Yes) & -0.001 & 0.182 & -0.01 & 0.995 \\
\hline Constant & 0.686 & 0.667 & 1.03 & 0.303 \\
\hline \multicolumn{5}{|c|}{ Number of observation $=898$} \\
\hline \multicolumn{5}{|c|}{$\operatorname{LR} \operatorname{chi}^{2}(14)=113.64$} \\
\hline \multicolumn{5}{|c|}{ Prob $>c h i^{2}=0.000$} \\
\hline \multicolumn{5}{|c|}{ Pseudo $R^{2}=0.100$} \\
\hline
\end{tabular}

Notes. ${ }^{* * *} \mathrm{p}<0.01,{ }^{* *} \mathrm{p}<0.05,{ }^{*} \mathrm{p}<0.1$. Source: computed from the data, 2019.

\section{Conclusions and Policy intervention}

Many soil and water conservation technologies have been popularized and disseminated in the country via research institutes and other development organizations. Despite research and development efforts, the low adoption of soil and water conservation technologies is the main challenge and driver to severe soil erosion and low agricultural productivity. This study was aimed to identify factors constraining the adoption of soil and water conservation practices. The result exhibited that $49 \%$ of farmers in the Oromia region use the SWC structures which are higher as compared to the SNNP 
region (44\%). The adoption rate of minimum tillage was also 36\%.

The econometric result revealed that extension service, participation on field day, radio ownership, oxen ownership, TLU, and training on soil and water conservation practices are among the drivers to low adoption of SWC technologies in the study area. Thus, policymakers should pay due attention to the problems affecting effective farmers-extension linkage since the role of extension service is beyond expert assistance in the adoption of SWC practices. It also enables a flow of information and transfer of knowledge and scientific findings. The agricultural extension workers have an effective and important role in helping local farmers solve soil erosion problems. The farmers' training center system which is partially functioning currently should also operate to its full capacity. The positive effect of radio ownership on technology adoption also suggests launching FM channels to farmers which initially focuses on the provision of SWC information and knowledge.

\section{References}

[1] Belay, S. (2016). Building community resilience to climate change: lessons from Choke mountain agro Ecosystems, Abay/the Blue Nile highlands. Addis Ababa university press, Addis Ababa, Ethiopia.

[2] Asnake, M., Heinimann, A., Gete, Z., and Hurni, H. (2018). Factors affecting the adoption of physical soil and water conservation practices in the Ethiopian highlands. Journal of International Soil and Water Conservation, 6(1): 23-30.

[3] Mohammed, G., Yan, D., Wang, H., Basaznew, A., Mersha, C., and Genenew, A. (2018). Determinant factors influencing crop production and adoption of soil and water conservation practices in Semen Mountain National Park, Ethiopia. International Journal of Environmental Sciences and Natural Resources, 13(2):555-558.

[4] Bekele, W. and Drake, L. (2003). Soil and water conservation decision behavior of subsistence farmers in Eastern highland of Ethiopia: A case study of the Hunde-lafto area. Journal of Ecological Economics, 46: 437-451.

[5] MoARD. (2010). Ethiopia's agricultural sector policy and investment framework (PIF) 2010-2020. Draft report, 1-15.

[6] Haile, G. H., and Fetene, M. (2012). Assessment of soil erosion hazard in Kilie catchment, East Shoa, Ethiopia. Journal of Land Degradation and Development, 23: 293-306.

[7] Tesfaye, A., Negatu, E., Brouwer, R., and Vaanderzaag, P. (2014). Understanding soil conservation decision of farmers in the Gedeb Watershed, Ethiopia. Journal of Land Degradation and Development, 25: 71-79.

[8] Bewket, W. and Teferi, E. (2009). Assessment of soil erosion hazard, and prioritization for treatment at the watershed level: a case study in the Chemoga watershed, Blue Nile Basin, Ethiopia. Journal of Land Degradation and Development, 20: 6-9-622.

[9] Abate, S. (2011). Estimating soil loss rates soil conservation planning in the Borena Woreda of South Wollo highlands, Ethiopia. Journal of Sustainable Development in Africa, 13:87-106.

[10] Berhan, G. and Mekonnen, K. (2009). Estimating soil. Loss using universal soil loss equation for soil conservation planning at Medego watershed, Northern Ethiopia. Journal of American Sciences, 5: 58-69.

[11] Nigatu, D., Kalkidan, F., and Tewodros, M. (2017). Soil and water conservation practices on crop productivity and its economic implications in Ethiopia: A review. Asian Journal of Agricultural Research, 1-9.

[12] Bewket, W. and Sterk, G. (2003). Assessment of soil erosion in cultivated fields using a survey methodology for rills in the Chemoga watershed, Ethiopia. Journal of Agriculture, Ecosystems and Environment, 97: 81-93.

[13] Tesfaye, A., Negatu, W., Brouwer, R., and Zaag, P. (2014). Understanding soil conservation decision of farmers in the Gedeb watershed, Ethiopia. Journal of Land Degradation and Development, 25: 71-79.

[14] Haregeweyn, N., Tsunekawa, A., Nyssen, J., Poesen, J., Tsubo, M., Meshesha, D. T., Schutt, B., Adgo, E., and Tegegne, F. (2015). Soil erosion and conservation in Ethiopia: A review. Progress in Physical Geography, 39: 750-774.

[15] Hurni, K., Zeleke, G., Kassie, M., Tegegne, B., Kassawmar, T., Teferi, E., Moges, A., Tadesse, D., Ahmed, M., Degu, Y., Kebebew, Z., Hodel, E., Amdihun, A., Mekuriaw, A., Debele, B., Deichert, G., and Hurni, H. (2015). Soil Degradation and Sustainable Land Management in the Rain fed Agricultural Areas of Ethiopia: An Assessment of the Economic Implications. Economics of Land Degradation (ELD) Ethiopia Case Study Report for the Economics of Land Degradation Initiative. P. 94.

[16] Mesfin, A. (2007). The Effect of different soil conservation structure on some properties of soil and crop yield in Dolechaw Woreda, Silte Zone, SNNPR. M.Sc. Thesis, Haramaya University, Haromaya, Ethiopia

[17] MoFED. (2006). Ethiopia: building on progress. A plan for accelerated and sustained development to end poverty (PASDEP) (2005/06-2009/10) Volume I: main text. Ministry of finance and economic development: Addis Ababa, Ethiopia.

[18] Kato, E., Ringler, C., Yesuf, M., and Bryan, E. (2011). Soil and water conservation practices: Is a buffer against production risk is the face of climate change? Insights from the Nile basin in Ethiopia. Agricultural Economics, 42: 593-604.

[19] Adimassu, Z., Mekonnen, K., Yirga, C., and Kessler, A. (2014). The effect of soil bunds on runoff, soil and nutrient losses, and crop yield in the Central Highlands of Ethiopia. Journal of Land Degradation and Development, 25: 554-564.

[20] Tesfaye, A., Deneke, T. T., and Selassie, Y. G. (2014). Determinants of maintenance decision of introduced soil and water conservation practices in Fagita Lekoma district, North West highlands of Ethiopia. Ethiopian Journal of Applied Sciences and 
Technology, 5: 1-17.

[21] Gessesse, B., Bewket, W., and Brauning, A. (2016). Determinants of farmers' tree planting investment decisions as a degraded landscape management strategy in the Central Highlands of Ethiopia. Journal of Solid Earth, 7: 639-650.

[22] Jansen, H. G. P., Rodriguez, A., Damon, A., Pender, J., Chenier, J., and Schipper, R. (2006). Determinants of income-earning strategies and adoption of conservation practices in hillside communities in rural Honduras. Journal of Agricultural Science, 88: 92-110.

[23] Awulachew, B. (2010). Constraints and opportunities for enhancing the system irrigation potential in Ethiopia: International water management institute.

[24] Tefera, B. and Sterk, G. (2010). Land management erosion problems and soil and water conservation in Finch'a watershed, Western Ethiopia. Journal of Land Use Policy, 27: 1027-1037.

[25] Fikru, A. (2009). Assessment of adoption behavior of soil and water conservation practices in the Koga watershed, highlands of Ethiopia. MSc. Thesis, Bahir Dar University, p. 62.

[26] Daniel, A. and Mulugeta, N. (2017). Factors affecting adoption of soil and water conservation practices: The case of Wereillu Woreda (District), South Wollo Zone, Amhara Region, Ethiopia. International Soil and Water Conservation Research, 275-279.

[27] Agere, B., Wuletaw, M., and Kavitha, N. (2020). Factors influencing the adoption of soil and water conservation practices in the Northwest Ethiopian highlands. International Soil and Water Conservation Research, 8: 80-89.

[28] CSA. (2018). The federal democratic republic of Ethiopia: Central Statistical Agency; agricultural sample survey 2017/18 (2010 E.C.) Report on area and production of major crops. (Private peasant holdings, meher season); Volume 1; statistical bulletin 586, Addis Ababa April, 2018.

[29] Hill, L. and Kau, P. (1973). Application of multivariate probit to a threshold model of grain dryer purchasing decisions. American Journal of Agricultural Economics, 55: 19-27.

[30] Pindyck, S. R. and Rubinfeld, L. D. (1998). Econometric models and economic forecasts, 4th edition, New York: McGraw-hill.

[31] Erenstein, O. (2003). Smallholder conservation farming in the tropics and sub-tropics: a guide to the development and dissemination of mulching with crop residues and cover crops. Agricultural, Ecosystem, and Environment, 100(1): 17-37.

[32] Hobbs, P. R. (2007). Conservation agriculture: what is it and why is it important for future sustainable food production? Journal of Agricultural Science, 145(2): 127.

[33] FAO and ITPS. (2015). Status of the World's Soil Resources (SWSR)-Technical Summary. Rome, Italy.

[34] Birhanu, A. and Meseret, D. (2013). Structural Soil and Water Conservation Practices in Farta District, North-Western Ethiopia: An Investigation on Factors Influencing Continued Use. Science, Technology, and Arts Research Journal, 2(4): 114-121.

[35] Damtew, A. A., Husen, M. A., and Demeku, M. A. (2015). Determinants of adopting the practice of soil and water conservation in Goromti Watershed, Western Ethiopia. Journal of Soil Science and Environmental Management, 6(6): 168-177.

[36] Asfaw, D. and Neka, M. (2017). Factors affecting adoption of soil and water conservation practices: The case of Wereillu district, South Wollo Zone, Amhara Region, Ethiopia. International Soil and Water Conservation Research, 5: 273-279.

[37] Issahaku, G. and Abdulai, A. (2019). Adoption of climate-smart practices and its impact on farm performance and risk exposure among smallholder farmers in Ghana. Agricultural and Resource Economics, 64(2): 396-420.

[38] Wordofa, M. G., Okoyo, E. N., and Erkalo, E. (2020). Factors influencing the adoption of improved structural soil and water conservation measures in Eastern Ethiopia. Environmental System Research, 9(13): 1-11.

[39] Belachew, A., Mekuria, W., and Nachimuthu, K. (2020). Factors influencing the adoption of soil and water conservation practices in the northwest Ethiopian highlands. International Soil and Water Conservation Research, 8: 80-89.

[40] Mulie, A. (2012). Adoption of soil and water conservation practices on farmlands: The case of karita Wuha Watershed, West Belessa district, North Gonder, Ethiopia. MSc. Thesis.

[41] Berhanu, A., Teddy, G., Dinaw, D., and Melese, B. (2016). Soil and water conservation practices: Economic and Econometrics, 4(1): 169-177.

[42] Yitayal, A., and Adam, B. (2014). The impact of soil and water conservation program on the income and productivity of farm households in Adama District, Ethiopia. Science, Technology, and Art Research Journal, 3(3): 198-203.

[43] Zemenu, D. A. and Minale, A. S. (2014). Adoption of soil conservation practices in North Achefer district, Northwest Ethiopia. Chinese Journal of Population Researches and Environment, 12(3): 261-268.

[44] Kwasi, A. D., Joana, D. K., Frank, A., and Daniel, B. S. (2019). Assessment of the determinants that influence the adoption of sustainable soil and water conservation practices in Techiman, municipality of Ghana. International Soil and Water Conservation Research, 7: 248-257. 